\title{
THE STUDY OF THE ELEMENTAL COMPOSITION OF SUMMER SQUASH (CUCURBITA PEPO L).
}

\author{
Yu.A.Fedchenkova, I.I.Batyuchenko, O.P.Khvorost \\ National University of Pharmacy
}

Key words: summer squash; leaves; stalks; flowers; elemental composition

\begin{abstract}
Using the method of atomic emission spectrometry the qualitative composition and quantitative content of elements in the raw material (leaves, stalks, flowers) of summer squash (Cucurbita pepo L.) collected at different stages of vegetation have been determined. It has been found that leaves, stalks, flowers have identical elemental composition: 5 macro-, 10 micro- and 4 ultramicroelements concerning the qualitative aspect. For macroelements the regularity of increase in the content at the stages of vegetation was observed. There is the following regularity of the elemental content for the raw material: leaves and flowers $-K>\mathrm{Ca}>\mathrm{Si}>\mathrm{Mg}>\mathrm{P}>\mathrm{Na}$, stalks $-\mathrm{K}>\mathrm{Ca}>\mathrm{Mg}>\mathrm{Si}>\mathrm{P}>\mathrm{Na}$. The highest content of potassium has been determined in all types of the raw material. The content of this element in stalk is $3340-5050 \mathrm{mg} / \mathrm{kg}$, and it is higher compared to leaves by 1.2-1.5 times (2850-3354 mg/kg), compared to flowers - by 1.1-1.3 times (3000-4000 mg/kg). In leaves, stalks and flowers the considerable content of calcium $(1350-1700 \mathrm{mg} / \mathrm{kg}, 1000-1576 \mathrm{mg} / \mathrm{kg}, 1007-1345 \mathrm{mg} / \mathrm{kg}$, respectively), silicon (1299-1400 mg/kg, 470-500 mg/kg, 1000-1130 mg/kg, respectively) and magnesium $(8000-1086 \mathrm{mg} / \mathrm{kg}, 759-800 \mathrm{mg} / \mathrm{kg}, 897-905 \mathrm{mg} / \mathrm{kg}$, respectively) has been found. The content of such elements as molybdenum, cobalt and lead is lower than $0.03 \mathrm{mg} / \mathrm{kg}$, arsenic, cadmium and mercury is lower than $0.01 \mathrm{mg} / \mathrm{kg}$. The considerable content of such elements as calcium, silicon and magnesium in the types of the raw material studied indicates that leaves, stalks and flowers of summer squash can be a source for obtaining BAS.
\end{abstract}

Nowadays despite a variety of synthetic medicines used in medical practice herbal drugs enjoy wide popularity. Our attention was drawn by summer squash $(\mathrm{Cu}$ curbita pepo L.), a melon plant. The plant is officinal, seeds are used as the raw material and an effective helminthagogue $[7,8]$. By the power of the pharmacological action the seeds of summer squash yield to the raw material of a male fern, but they do not show toxic effect on the organism. It is also known that the pulp of summer squash increases the biliary excretion, improves the function of intestines in spastic colitis [2], intensifies the water-salt exchange, the renal filtration function, provides intensive release of chloride ions by the kidneys (promotes urination), has antioxidant properties, is an irreplaceable product in dietary food $[10,13]$.

The chemical composition of the officinal raw material is rather studied. The seeds contain fatty oil (about $20 \%$ ), phytosterol cucurbitol, resinous substances, organic acids, vitamins of group B, ascorbic acid. The pulp contains sugars (glucose, fructose, sucrose), organic acids (mainly malic), carotene (up to $6 \mathrm{mg} \%$ ), ascorbic $(8-20 \mathrm{mg} \%$ ), folic $(14 \mathrm{mg} \%)$, pantothenic $(0.4 \mathrm{mg} \%)$ and nicotinic $(0.5 \mathrm{mg} \%)$ acids, vitamins $\mathrm{B}_{1}, \mathrm{~B}_{2}, \mathrm{~B}_{6}(0.13 \mathrm{mg} \%)$, a significant amount of mineral substances (potassium, calcium, phosphorus, iron, copper, fluorine, zinc) $[6,9,11]$. Data on the chemical composition of stalks, leaves and flowers of summer squash is fragmentary. It is known that leaves contain up to $620 \mathrm{mg} \%$ of ascorbic acid, vitamins of group B, $438 \mathrm{mg} \%$ of potassium, $43 \mathrm{mg} \%$ of calcium, $38 \mathrm{mg} \%$ of magnesium and not less than $7 \mathrm{mi}-$ neral compounds, flowers have flavonoids and xanthophylls - cryptocapsin, zeaxanthin, flavoxanthin [5].

The mineral status of a plant is determined by the combined effect of different both necessary, and harmful mineral elements found in it. The Polish scientist Ya. Yancharsky arrived at the conclusion that the combination of three elements - magnesium, calcium and silicon was required for the correct metabolism. In turn, $\mathrm{K}$. Riger proved that the main role of calcium in a human body was $\mathrm{pH}$ balancing (fight against "acidulation") and the help in killing cancer cells. Calcium also determines the selective permeability of cellular membranes, and its lack leads to increase in diffusion of various substances through membranes. Silicon increases the immunity, provides elasticity of vascular walls, has a positive effect on the protein biosynthesis, takes part in the connective tissue formation. Magnesium prevents from development of atherosclerosis, it is important in cardiovascular diseases, CNS excitation, diabetes, etc., is a part of chlorophyll molecules. The role of sodium in the life of a plant has not been finally found; this element promotes the creation of high osmotic pressure in cells.

The important indicator of the plant mineral status is the ratio of $\mathrm{K}^{+} / \mathrm{Na}^{+}$, for it there are certain regular changes that are distinctive for different organs (root, leaves) of the plant. Researchers consider that the content of $\mathrm{Na}^{+}$at the level of $10 \mathrm{mg} / \mathrm{kg}$ in different plants is standard [12].

Based on the aforementioned the expansion of the source of the raw material for creation of new domestic medicines of the plant origin, the study of the chemical 


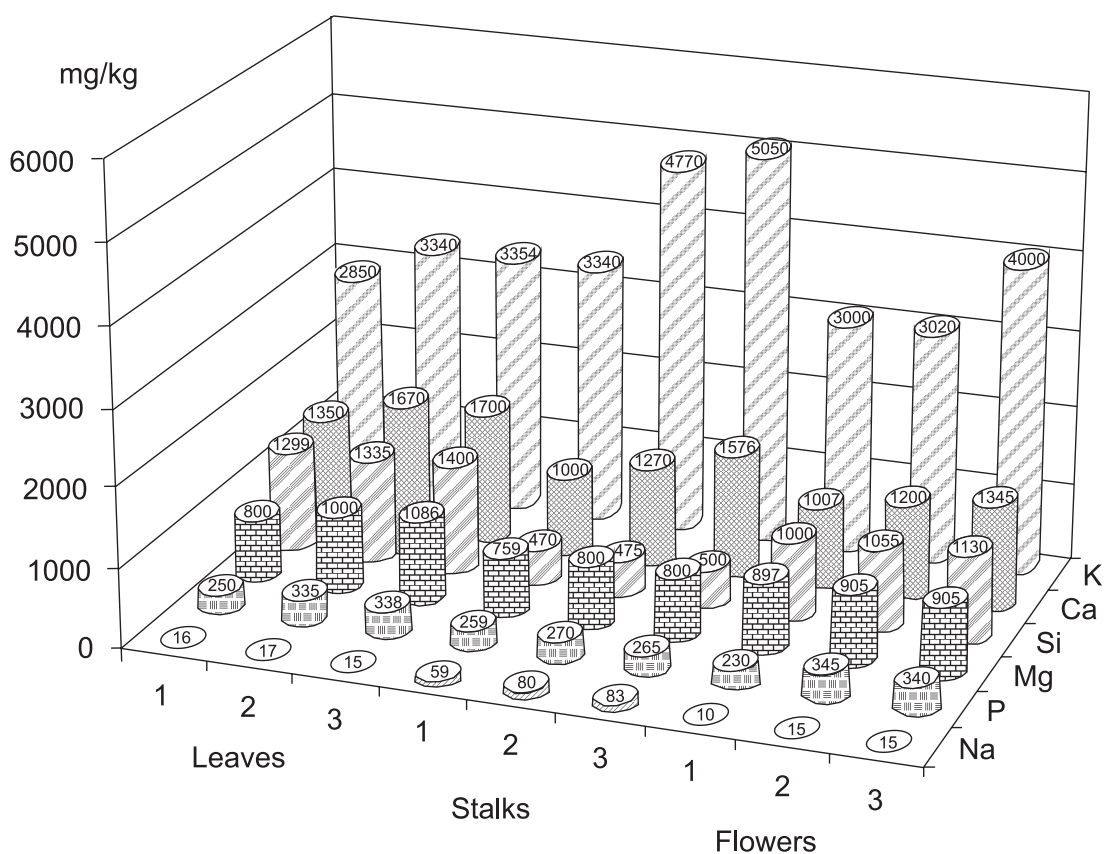

Fig. 1. Macroelemental composition of the raw material of summer squash. Stage 1 - the period of full opening of the leave blade (flowers were gathered as buds), stage 2 - the blossom period, stage 3 - the beginning of fructification.

composition of the raw material of summer squash, including the elemental one, is of current importance [3].

The aim of our research was to study the elemental composition of leaves, stalk and flowers of summer squash collected in different stages of vegetation.

\section{Materials and Methods}

The raw material (leaves, stalks, flowers) of summer squash, "Ukrainian polycarpous" sort [4], collected at different stages of vegetation in the Kharkiv region became the object of our research: stage 1 - the period of full deployment of a leaf blade (flowers were collected in the form of buds), stage 2 - the blossoming period, stage 3 - the period of the beginning of fructification. The study of the elemental composition was performed at the premises of the State Scientific
Institution "Institute for Single Crystals" of the NAS of Ukraine (Kharkov). The method of atomic emission spectrometry with photographic registration of results was used [1].

\section{Results and Discussion}

The diagram of the macroelemental composition of leaves, stalk and flowers of summer squash at different stages of vegetation is given in Fig. 1, the diagram of the microelemental composition is presented in Fig. 2.

It has been found that all types of the raw material leaves, stalks and flowers concerning the qualitative aspect have the identical elemental composition presented by 19 elements. For macroelements the regularity of increase in the content at the stages of vegetation was observed (see Fig. 1). There is the following regulari-

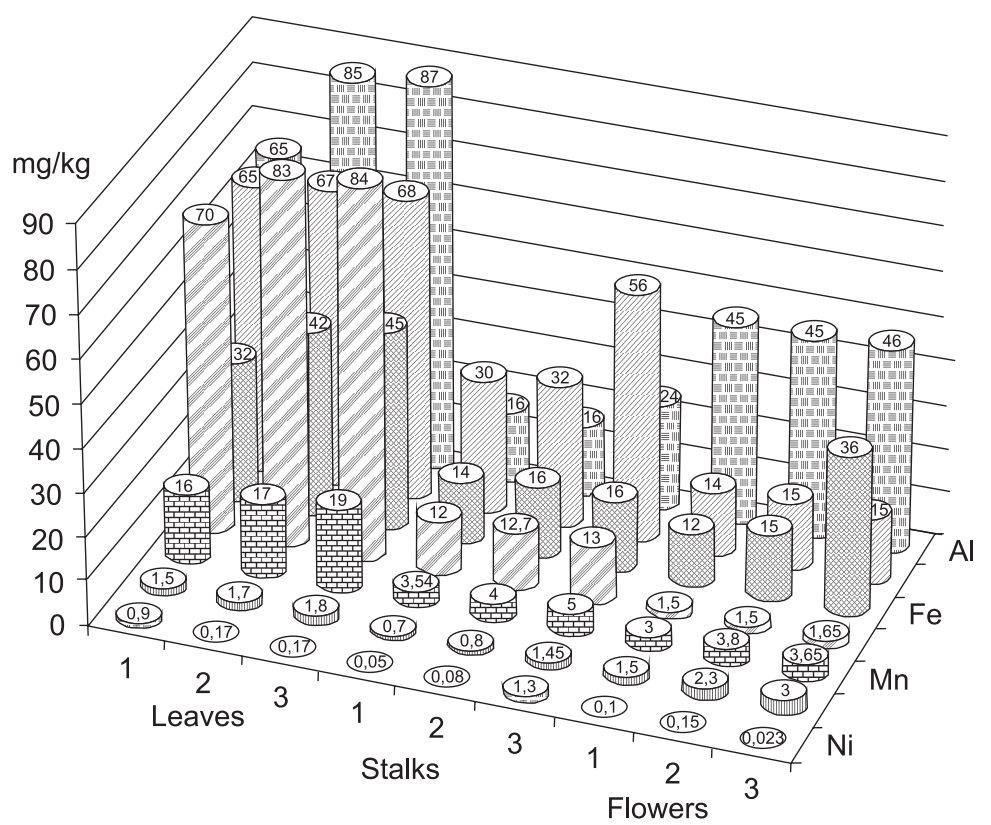

Fig. 2. Microelemental composition of the raw material of summer squash. Stage 1 - the period of full opening of the leave blade (flowers were gathered as buds), stage 2 - the blossom period, stage 3 - the beginning of fructification. 
ty of the elemental content for the raw material: leaves and flowers $-\mathrm{K}>\mathrm{Ca}>\mathrm{Si}>\mathrm{Mg}>\mathrm{P}>\mathrm{Na}$, stalks $-\mathrm{K}>$ $\mathrm{Ca}>\mathrm{Mg}>\mathrm{Si}>\mathrm{P}>\mathrm{Na}$. The content of such elements as molybdenum, cobalt and lead is lower than $0.03 \mathrm{mg} / \mathrm{kg}$, arsenic, cadmium and mercury is lower than $0.01 \mathrm{mg} / \mathrm{kg}$. The highest content in 3 types of the raw material is determined for potassium. The content of this element in stalk is $3340-5050 \mathrm{mg} / \mathrm{kg}$, and it is higher compared to leaves by $1.2-1.5$ times $(2850-3354 \mathrm{mg} / \mathrm{kg})$, compared to flowers - by 1.1-1.3 times (3000-4000 mg/kg). In leaves, stalks and flowers the considerable content of calcium (1350-1700 mg/kg, 1000-1576 mg/kg, 1007-1345 mg/kg, respectively), silicon (1299-1400 mg/kg, 470-500 mg/kg, $1000-1130 \mathrm{mg} / \mathrm{kg}$, respectively) and magnesium (8000$1086 \mathrm{mg} / \mathrm{kg}, 759-800 \mathrm{mg} / \mathrm{kg}, 897-905 \mathrm{mg} / \mathrm{kg}$, respectively) has been found.
The considerable content of such elements as calcium, silicon and magnesium in the types of the raw material studied indicates that leaves, stalks and flowers of summer squash can be a source for obtaining BAS.

CONCLUSIONS

1. Using the method of atomic emission spectrometry the qualitative composition and quantitative content of elements in the raw material of summer squash $(\mathrm{Cu}$ curbita pepo L.) collected at different stages of vegetation have been determined.

2. All types of the raw material - leaves, stalks, flowers in qualitative terms have the identical elemental composition. In each type of the raw material 5 macro-, 10 micro- and 4 ultramicroelements have been found. For all types of the raw material the highest content of potassium has been observed.

\section{REFERENCES}

1. Бурда Н.С., Журавель І.О., Кисличенко В.С., Дємьохін В.Б. // Збірник наукових праць співробітників НМАПО ім. П.Л.Шупика. - 2010. - Вип. 19, кн. 3. - С. 586-589.

2. Вахрушев Я.М., Петрова Л.И. // Клиническая медицина. - 2004. - №10. - С. 49-51.

3. Государственная фармакопея СССР. Вып. 2. Общие методы анализа. Лекарственное растительное cырье / МЗ СССР. - 11-е изд. - М.: Медицина, 1989. - 400 с.

4. Колесник I.I., Заверталюк В.Ф. - Дніпропетровська дослідна станція ІОБ НААН. - Дніпропетровськ, 2011. -10 c.

5. Ел. ресурс: http://www.rusagroweb.ru/-Овощуеводство в России. Питательная цуенность тыквы.

6. Azevedo-Meleiro C., Rodriguez-Amaya D. // J. Agric. Food Chem. - 2007. -Vol. 55, №10. - P. 4027-4033.

7. Caili F., Huan S., Quanhong L. // Plant Foods Hum. Nutr. - 2006. - №61. - P. 73-80.

8. Harchuk O.A., Mitina T.F., Kirilov A.F. et al. // Bul. IAŞM. Ştințelevieți. Fiziologiasi Biochimia Plantelor. 2013. - №1 (319). - C. 71-78.

9. Kim M.Y., Kim E.J., KimY.N. et al. // Nutr. Res. Pract. - 2012. - Vol. 6, №1. - P. 21-27.

10. Saldeen K., Saldeen T. // Nutr. Res. - 2005. - №25. - P. 877-889.

11. Salwa E., Qiping Y., Ibrahim F. et al. // East African J. of Sci. - 2010. - Vol. 1, №1. - P. 77-89.

12. Taiz L., Zeiger E. Plant Physiology, $4^{\text {th }}$ ed. Sinauer Associates. 2006. Inc. Sunderland, MA (QK711.2.T35 2006). $-705 \mathrm{p}$

13. Wagner K.H., Kamal-Eldin A., Elmadfa I. // Ann. Nutr. Metab. - 2004. - №48. - P. 169-188.

\section{ДОСЛІДЖЕННЯ ЕЛЕМЕНТНОГО СКЛАДУ СИРОВИНИ ГАРБУЗА ЗВИЧАЙНОГО}

\section{CUCURBITA PEPO L.}

Ю.А.Федченкова, І.І.Батюченко, О.П.Хворост

Ключові слова: гарбуз звичайний; листя; стебла; квітки; елементний склад

Методом атомно-емісійної спектрометрії визначено якісний склад та кількісний вміст елементів у сировині (листі, стеблах, квітках) гарбуза звичайного Cucurbita pepo L., зібраній у різні стадії вегетації. Встановлено, що листя, стебла, квітки в якісному плані мали однаковий елементний склад: 5 макро-, 10 мікро- та 4 ультрамікроелементів. Для макроелементів спостерігалася закономірність збільшення вмісту по стадіях вегетації. Має місце певна закономірність вмісту елементів для сировини: листя та квіток-K> Ca $>\mathrm{Si}>\mathrm{Mg}>\mathrm{P}>\mathrm{Na}$, стебла $-\mathrm{K}>\mathrm{Ca}>\mathrm{Mg}>\mathrm{Si}>\mathrm{P}>\mathrm{Na}$. Всім видам сировини був притаманний високий вміст калію. Так, для стебла він становив 3340-5050 мг/ке, що вище порівняно з листям в 1,2-1,5 рази (2850-3354 мг/к2), а порівняно із квітками - в 1,1-1,3 рази (3000-4000 мг/к2). В листі, стеблах та квітках теж у значних кількостях містилися кальцій (1350-1700 мг/ке, 1000-1576 мг/ке, 1007-1345 мг/ке, відповідно), силіцій (1299-1400 мг/ке, 470-500 мг/ка, 1000-1130 мг/кг відповідно) та магній (8000-1086 мг/ке, 759-800 мг/ке, 897-905 мг/ке відповідно). Вміст таких елементів як молібден, кобальт та плюмбум нижчий за 0,03 мә/ка, вміст арсену, кадмію та меркурію - нижчий за 0,01 мг/ке. Значний вміст таких важливих елементів як кальцій, силіцій та магній у досліджуваних видах сировини свідчить про те, що листя, стебла та квітки гарбуза звичайного можуть стати джерелом отримання цих БАР. 


\section{ИССЛЕДОВАНИЕ ЭЛЕМЕНТНОГО СОСТАВА СЫРЬЯ ТЫКВЫ ОБЫКНОВЕННОЙ} CUCURBITA PEPO L.

\section{Ю.А.Федченкова, И.И.Батюченко, О.П.Хворост}

Ключевые слова: тыква обыкновенная; листья; стебли; иветки; элементный состав Методом атомно-эмиссионной спектрометрии определен качественный состав и количественное содержание элементов в сырье (листьях, стеблях, цветках) тыквы обыкновенной Cucurbita pepo L., заготовленном в разные стадии вегетации. Установлено, что листья, стебли, цветки в качественном плане имели одинаковый элементный состав: 5 макро-, 10 микрои 4 ультрамикроэлемента. Для макроэлементов наблюдалась закономерность увеличения содержания по стадиям вегетации. Наблюдается определенная закономерность содержания элементов для сырья: листьев и иветков $-\mathrm{K}>\mathrm{Ca}>\mathrm{Si}>\mathrm{Mg}>\mathrm{P}>\mathrm{Na}$, стеблей $-\mathrm{K}>\mathrm{Ca}$ $>\mathrm{Mg}>\mathrm{Si}>\mathrm{P}>\mathrm{Na}$. Для всех видов сырья было характерно высокое содержание калия. Так, в стеблях оно состаляло 3340-5050 мг/ка, что выше по сравнению с листьями в 1,2-1,5 раза (2850-3354 мг/к2), а по сравнению с цветками - в 1,1-1,3 раза (3000-4000 мг/к2). В листьях, стеблях и цветках тоже в значительном количестве содержался кальций (1350-1700 ма/ка, 10001576 мг/ка, 1007-1345 ма/ка соответственно), кремний (1299-1400 мг/ка, 470-500 мг/ка, 10001130 мг/ке соответственно) и магний (8000-1086 мг/к2, 759-800 мг/ке, 897-905 мг/к2, соответственно). Содержание таких элементов как молибден, кобальт и свинец ниже 0,03 мг/к2; мышьяка, кадмия и ртути - ниже 0,01 мә/ка. Значительное содержание таких важных элементов как кальций, кремний и магний в исследуемых видах сырья свидетельствует о том, что листья, стебли и цветки тыквы обыкновенной могут стать источником получения этuх БAB. 